\title{
Home Stay Statistics and its Outcomes in Rural Community Based Tourism in Nepal
}

\author{
Ishwari Prasad Banjade ${ }^{1}$
}

\begin{abstract}
Home-stay is new model of tourism development in Nepal which provides an excellent opportunity to share, see and feel the diverse countryside lifestyle, local culture, and tradition. It promotes the rural economy through the promotion of rural tourism. The article aims to assess the economic contribution of homestay entity of Nepal, based on the descriptive and exploratory research design. Data were collected from the 8 home stays out of 45 listed in Nepal Tourism Board. 55 households were selected randomly from 8 home-stays from different location from the hinter land of Kathmandu valley. The result based on statistics reflect the significant increase in income and expenditure of local people in study areas. It is found that majority of respondents have managed their household expenditure from the income from home-stay. The income status of home stays in study areas was found good. All home-stay operators have reported the increment in their savings and credit activities which directly contributes to the improvement in their economic status. However, it is also found that there need to improve the quality in home stays to increase the income of home-stay operator. The inequality pattern of male is more than women and have equal decision making status.
\end{abstract}

Key Words: Contribution, Socio-economic, Home-stay, Respondents,

\section{Introduction}

Home stay tourism is considered as part of village tourism which play vital role in contributing local economy. Village tourism denotes tourists visiting villages and staying in or near the villages. Many cases have shown that the village should have special features to attract visitors. This is also associated with tourist behavior in that they stay in a village and explore the atmosphere. The special feature of this kind of tourism is that the visitors become part of the village for the period of their stay. They rely on locally available accommodation and others facilities.

Home stay tourism is pleasing to all around the world. Some people believe that the home stay scheme can address the issues of poverty. However, other, especially who pay more attention towards the income poverty argue that the home stay tourism can help lowering poverty. It is believed that, the home stay tourism can support empowering

1 Mr. Banjade is Lecturer at Central Department of Statistics, T.U. 
local communities through preserving their majestic culture, which is considered as one of the major components of the economy. In addition, the indirect positive impact and induced of home stay tourism can be seen in the income of rural poor.

The home stay program educates visitors to the local culture, wisdom and traditional way of life. The culture includes religion, vibrant customs, weaving, games, musical instruments etc. The home stay program educates visitors to the local culture, wisdom and traditional way of life.

The culture includes religion, vibrant customs, weaving, games, musical instruments, dress, architecture, picking fruits in the orchard and involving in farming etc. Similarly, the wisdom includes the local history, fables and knowledge on traditional herbal medicines and other indigenous resource management system. Home stay program is for those who wish to gain a greater understanding of each other's customs, culture and way of thinking through involving and experiencing the daily lives of local people. It creates an opportunity to aware tourists on socio-economic and cultural issues of the destination sites. Thus, the strategy ultimately supports for conservation of the destination culture, which has been considered as one of the major components of the local economy. In this regards, social awareness, family support gender equality, women empowerment safety and security, quality education and job orientation, training are seemed inevitable factors. On the other hand male dominancy, gender discrimination and sexual harassment should be avoided for the bright prospect of female employment in tourism. It can be said that that the prospect of female employment seems very bright in every sectors of tourism in Nepal (Dhital, 2009).

The home stay tourism does not seek to address the question; "how can communities benefit more from tourism, it seeks instead how tourism can contribute to the process of cultural conservation?". Promoting community pride and preserving the unique character and culture of the local area should be the prime objective of home stay programme. Home stay is a special package, where one can have the opportunity to stay with farmers and gain the experience pertaining to farmers' and villagers' unique daily activities such as exploring village, participating in different farm activities, witnessing farming practice etc. In addition, tourists have an opportunity of enjoying the warm hospitality of the host family and be a part of the household members by joining them in their daily activities. It allows tourists to discover the origins of village and rich history it holds. The study explores the strength of home stays in terms of socio-economic and cultural aspect.

\section{What Literature Says?}

The home stay program is regarded as a community-based tourism product by many nations. Despite the enormous growth of the home stay program in Malaysia, the industry faces numerous new challenges. A moderate level of service quality was one of the main factors contributing to their poor performance. Similar cases can be found in Nepalese home stays.

Home stay tourism affords the villages a level of connectedness that the other villages in 
the valley are not provided. Consequently, Munsiyari and Sarmoli are home to multiple shops, tourist accommodations, and restaurants the largest population in the Valley. One type of tourist accommodation found in Sarmoli is the homestay. It differs from typical accommodations by offering the traveler a unique experience that combines ones basic needs (food, shelter) with the host's culture. Recently, a popular trend called "home stay tourism" has emerged in Darjeeling, in which tourists choose to stay in small, familyowned homes rather than in large, commercialized hotels and resorts. Similar pattern is found many parts of the Nepal. This increasing demand for home stays may be explained by recent global social and cultural changes resulting in greater interest and appreciation in cultural heritage, lifestyles and environmental concerns. As a result, home stay ownership has developed as a form of alternative livelihood in both urban and rural areas throughout Darjeeling, with potential for social, cultural, and economic benefits for men as well as women. Previous studies exploring the impacts of tourism on rural communities conclude that the micro- businesses of local home stays provide a multitude of benefits for women, including increased financial stability, employment, improved inter-household relationships, and greater access to various social goods (Christian, 2012).

NRB (2015) pointed out the contribution of tourism sector on Nepal's GDP which has remained low despite immense potentiality. A reason for an underperformance of the sector is poor capacity for accommodating the tourists. Further, the tourism benefits have not reached to the residents equally. In later days, the homestay activities have begun in different parts of the country in pursuit of remarkable progress in the tourism sector. It is estimated that the community-based homestay systems can presently serve around 1 million guests in Nepal. The study finds that the income from homestay alone is covering around $4 / 5$ th of their family expenses and this has helped them to achieve a saving rate of 45.1 percent.

The findings revealed that homestay accommodation is a significant means of boosting the socio-economic well-being of rural people. This finding can be useful to the government (policy makers) in crafting policies and relevant legislation to create an enabling environment to encourage the growth and development of the homestay tourist accommodation sub-sector in a sustainable manner. This study explored 'hospitality experiences' in a non-commercial setting and defined homestays as enterprises whose main aim is to experience life of local people. It gave a better understanding of hospitality by discussing consequences of the phenomenon of hosting a commercial home. The guests who stayed in the house had to conform to the host's rules and be tolerant of host's idiosyncratic 'tyrannical' behavior.

Acharya and Elizabeth (2013) studied home stay tourism as popular in many destinations; it adds authentic sociocultural richness to the tourist's experience. For a nation that cannot make extensive infrastructural investment a priority but which possesses an abundance of tourism richness in remote communities, home stays are an attractive alternative tourism product. The essence of Nepalese tourism lies in naturally beautiful rural hills and mountains and its indigenous communities with their mystical lifestyle and culture. (Ismail, et al. 2015) discussed the home stay program 
as a community-based tourism product by many nations. Despite the enormous growth of the home stay program in Malaysia, the industry faces numerous new challenges. A moderate level of service quality was one of the main factors contributing to their poor performance. These phenomena can be observe in Nepalese home stays and have many issues related to the quality services.

Kimaiga (2015) studied home stay which may not impact directly to the poor but indirect and induced impact can be expected. Home stay features, generally require a home with, at least one extra room, bedding, pillow, mosquito net, laundry service, a desk for study, desk lamp, safe heater in their room, etc. Proper sanitation, hospitality and hygiene are important components of home stay tourism, which we cannot hope from the poor family, at least for a short run in Khumbu region. It is widely reported that the higher benefit of home stay tourism in Sirubari Village has been reaped by the well-to-do families. The programme has been initiated by British Gurkha Families, having unusual level of prosperity, education and English language. In addition, home stay programme should be considered as an incremental income and livelihood opportunity from the incremental activity to the local community. These realities should be replicated to promote the home stays in different home stays in Nepal. Home stay is a delicate social and cultural issue for the community. A home stay should not focus merely on providing accommodation for profit while ignoring cultural exchange and respect for the hosts culture.(Suansri,2003).In context of Nepal, some home stays plays very good role to promote the local culture. It can be found in Ghale gaun and sirubaree. Similarly the home stay tourism, is very important to educate the local communities that the scheme is not equivalent to the other lodges and hotels. They should be educated about the higher value of their way of life, dress and architecture, tradition knowledge and wisdom. Poor people can be mainstreamed in the home stay tourism activities by being tourists guide, community guide, community resource person, supporting accommodation, food etc.

In conclusion, home stay tourism could be developed as an instrument to preserve the local culture in a long run in hinterland of Kathmandu valley. It can be used to conservation of local culture, one of the essential components of local economy, supports for lowering the poverty issues in Nepal. Community should understand that the home stay tourism is not the hotel or lodge type of accommodation but flourish on the traditional way of life.

Home stay tourism is popular in many destinations; it adds authentic sociocultural richness to the tourist's experience. The data was derived through community-based action research and evaluation methodologies. Information was based on first-hand experiences generated through ethnographic observations and semi-structured interviews.

Biswakarma (2013) rightly observed that the satisfaction of customer in home stays depends on five factors such as Amenities and safety, reception, local cuisine, accommodation, local life style $\&$ customs and cultural performance. The results indicate a moderate tourist satisfaction level towards home stay. This also contributes to the development of survey instrument for exploring tourist satisfaction for Homestay for the future researchers in Nepal. 
58 | The Economic Journal of Nepal (Issue No. 149)

\section{Objectives of the Study}

The main objective of this study is to explore the income and employment status, perception from the home stays.

\section{Importance of the Study}

This study will be helpful to make rational plan in local level related to home stay in tourism sectors.

\section{Materials and Methods}

The study was based on the descriptive as well as exploratory research design which gives the ideas related to data generation and its management. This study was conducted in hinterland of Kathmandu valley. The design focused to identify the employment status of women in study area and also beneficial to understand the different problems faced by domestic tourism particularly in home stays.

\section{Selection of sample from population and sampling techniques}

The existing home stay program of hinterland of Kathmandu valley is considered as the main study area. The home stays listed in NTB was found 45 which was considered as the population size of the study. Among these population elements, 8 home stays from the total were selected as sample home stays using judgment sampling (non-random). Similarly 55 households were chosen randomly from those selected home stays.

\section{Data collection strategy}

Data collection strategies include both primary and secondary sources of information. After identification of sample units relevant to the study the tools such as questionnaires, interview, focal group discussion and observation were conducted to draw the rational information associated with home stays. The secondary sources of information were collected through reviewing existing literatures.

\section{Data analysis tools and techniques}

The collected data were systematically organized after editing and processing. In this study some statistical soft-ware are used such as (SPSS, Ex-cell) for data analysis. Qualitative data were analyzed by recording the interview on the basis of narration made by respondents. Similarly thematic and contents analysis was made using some social science ground theory.

\section{Validation}

The results of the study were validated using statistical tools as well as qualitative analysis. Similarly Literatures as well as qualitative analysis was also use to verify the quantitative result. . The overall achievement of this research was depended on effective data analysis tools and validation of information. 


\section{Results and Discussions}

\section{Status of Female Employment in Home Stay Tourism}

Tourism statistics 2013 indicates that a total of 797616 tourists visited Nepal in 2013. But there is no the data of home stay statistic. The ratio of tourist visit and employment generated suggests that, one employment was generated from every 6 tourist visit over one year period. The survey respondents perceived that inadequate infrastructure, inadequate promotion activities and regularity mechanism, political unrest, lack of skilled human resources and unhealthy competition among tourism establishments were some major barriers faced by the tourism and women employment sector. The respondents suggested that the government should develop tourism infrastructure including road, electricity and communication and implement tourism promotion activities. There is also an urgent need to invest more on improving hospitality skill of employees for quality tourism in Nepal. (Tourism Employment Survey,2014).From this background it can be reflected that female employment have the better prospect in home stays.

\section{Work load of male and female in study area}

The collected information were organized and tabulated. Simple statistical tools were used to find the average work load of the respondents from the study areas. The average work load of female was found $2.9273 \mathrm{hr} \pm .85753 \mathrm{hr}$ with variance $.735 \mathrm{hr}$. The maximum involvement of female in home stay tourism was found 8 hours while womens with 2 hours are few in number.But the modal values of working hours by women was found 5 hours covering $49.09 \%$. This figure shows the female involvement in the home stays in the hinterland of the kathmandu valley.

Table 1: Work Load Distribution of Female in Sampled Home Stay

\begin{tabular}{|c|c|c|}
\hline In hours work load by female /day & Frequency & Percentage \\
\hline 0 to 2 & 2 & 3.6 \\
\hline 2.1 to 4 & 14 & 25.45 \\
\hline 4.1 to 6 & 27 & 49.09 \\
\hline 6.1 to 8 & 9 & 16.36 \\
\hline 8.1 to 10 & 3 & 5.4 \\
\hline Total & 55 & 100 \\
\hline
\end{tabular}

Source:Field survey 2016 
60 | The Economic Journal of Nepal (Issue No. 149)

Figure 1: Work Load Distribution of Female in Sampled Home Stay

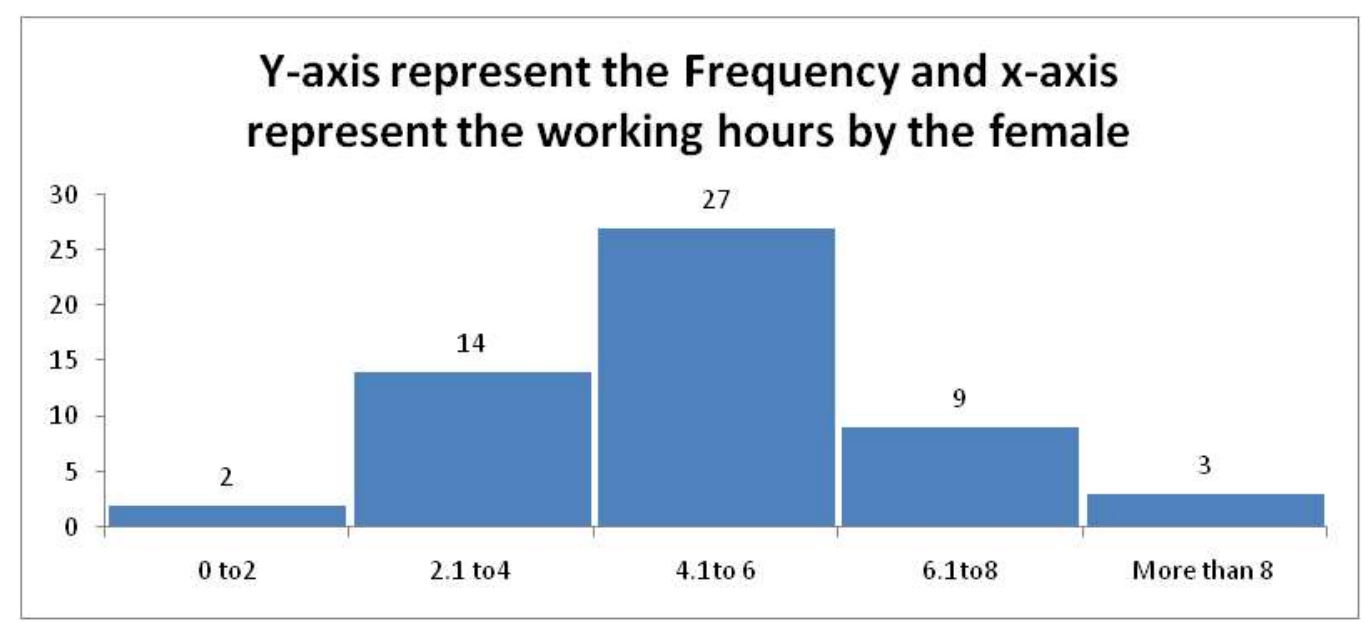

Source: Based on the table no. 1.

About $36.36 \%$ of males worked 1 hour per day in their home stay. Similarly, $32.72 \%$ of males worked 2 hours per day. The involved males with workloads greater than 4 hours are very few in number. Survey results indicate that the working loads by male was found comparatively lower than that of the females i.e. the size of males in home stay was found lower as compare to females.

Table 2: Working Hours by Male Involved in Sampled Home Stay

\begin{tabular}{|c|c|c|}
\hline Work load by male in hours /day & Frequency & Percentage values \\
\hline 0 to 2 & 7 & 12.7 \\
\hline 2.1 to 4 & 20 & 36.36 \\
\hline 4.1 to 6 & 18 & 32.72 \\
\hline 6.1 to 8 & 8 & 14.54 \\
\hline 8.1 to 10 & 2 & 3.6 \\
\hline Total & 55 & 100 \\
\hline
\end{tabular}

Sources: Field Survey, 2016

The mean working hours by male was found as 1.67 hours with 0.67 hours standard deviation which was statistics from 55 respondents. The $12.7 \%$ respondents were found involved less than two hour by the males where as $3.6 \%$ female were found to involved in same working status. It shows the more involvement by the women in the home stays in the study areas. 
Figure 2: Working Hours by Male Involved in Sampled Home Stay

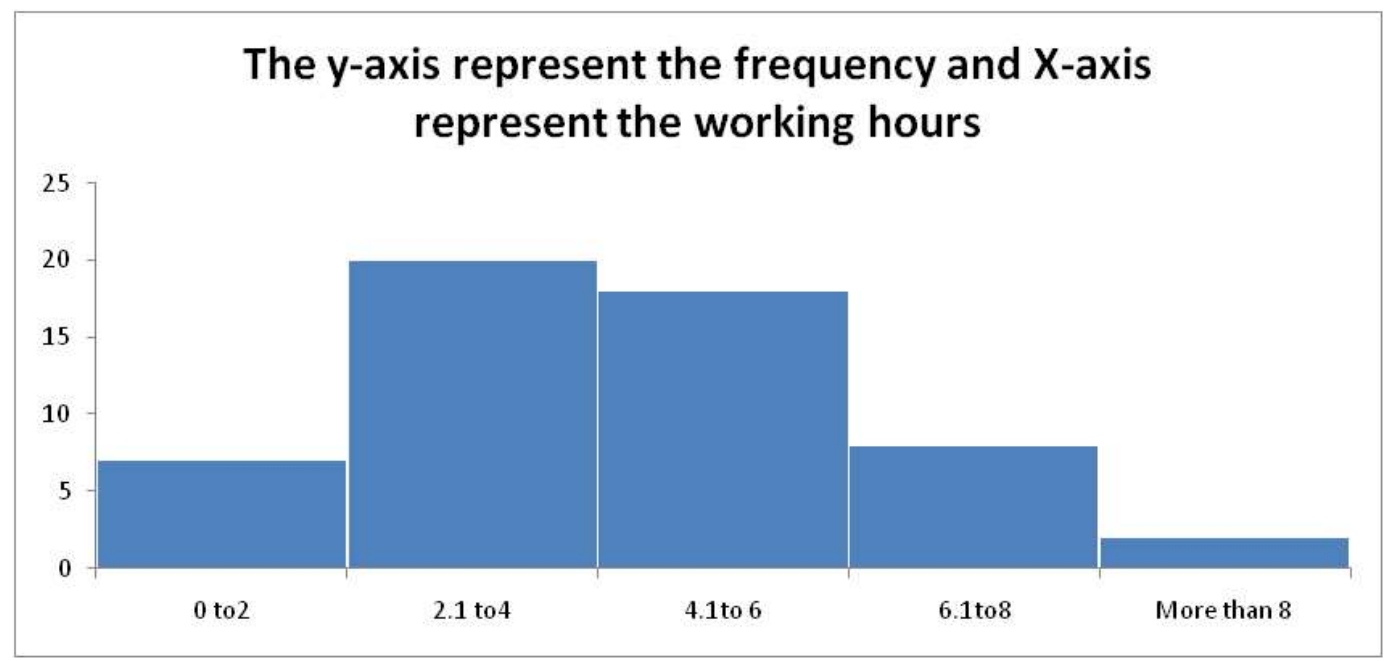

Source: Based on the table no. 2.

It is clearly reflected that the work loads of males is found significant different as compare with female for example the result of Chi-Square $=57.465, p=.000$.It reflect that the working hours of males in home stays in all the area is found differ and lower as compare with female.

There was significant difference in women involvement during 2010, 2011 and 2012 by Chi-Square $31.455,32.5545$ and 30.545 respectively with $\mathrm{p}=.000 .1$

The frequency distribution pattern by male and female is found differ according to chisquare value. The goodness of fitting of frequency distribution pattern by male is far away as compare to female. The shape of the curve of female is more normal than male. Hence the female have better employment status as compare to the male.

\section{Income and Expenditure}

The mean values of income generated from home stays in 2010 were Rs 48129.6296 \pm Rs4955.04717. Similarly, investment in tourism was Rs29977.7779 \pm Rs 3581.39061. The difference in mean values from the income and expenditure is Rs 18151.8517 showed positive effect in the home stays. Similar pattern is found regularly in three years. Income and expenditure are moderately related in the year of 2010, 2012 and 2013. $(\mathrm{r}=.598$,).

The ANOVA of Regression between income and expenditure in 2010 pointed out that the investment value is lower than income (ANOVA, $\mathrm{F}=28.969, \mathrm{p}=.000$ ). This data also reflects that income and expenditure both are significantly different with different household incomes. The expenditure was also significantly differed in $2010(t=5.382$ unit, $\mathrm{p}=.000)$. 
62 | The Economic Journal of Nepal (Issue No. 149)

The income patterns in households was not significantly different in 2010, 2011 and 2012 but 2012 is more profitable year in case of income generation as compare to others years.(Chi- Square $42.296, \mathrm{p}=0.331,48.556, \mathrm{p}=0.117$ and 18.889, $\mathrm{p}=0.998$ which are the respective consecutive chi-square values)

\section{Tourist Flow and Involvement by Female}

The rate of tourist flow and women involvement in the working activities in home stay in 2010 was perfectly related with female with their work load. $(r=1$,$) . Similarly$ the rate of tourist flow in 2011 and 2012 showed high degree of relationship with female work load $(\mathrm{r}=.861$,$) . Work load (\mathrm{r}=0.805$,$) .$

\section{Decision Making}

About 65.45 percent of respondents strongly mentioned that sharing of work load of males was low as compare to female. Similarly, 96 percent of the respondents mentioned that female employment is extremely beneficial in contributing upliftment of local economy and improvement of livelihoods within the community. Women were found empowered in home stays. Similarly they were found strong in decision making activities.

\section{Gini Coefficient about the Income of Male and Female}

The value of $\mathrm{GC}$ for male was found 0.439 which is higher than the GC for female i.e. 0.426. The income inequality, of male is higher than female. As we know the lower the value of G.C higher will be value of Human Development Index (HDI) (Sen, 1990). So $\mathrm{GC}$ is associated with welfare and development. Hence home stay programme contribute in human development sectors.

\section{Conclusion}

The study measures the level of income and expenditure of home-stay and female were found more dynamic as compare to male in the home stays. Income is relatively higher than the expenditure and correlation test shows the positive relation between the income and expenditure which indicate the increment of saving and credit activities. It shows that the economic status of home-stay was in increasing order and women are found directly involved in economic activities. The work load of female and tourist flow is highly correlated. Similarly the distribution pattern of working hour and frequency distribution of male and female is found differ as compare to both shape. The GC of male is more than female which reflect the positive impact of home stay programme towards women. 


\section{References}

Acharya, B.P. \& Halpenny, E.A. (2013). Homestays as an alternative tourism product for sustainable community development: A case study of women-managed tourism Tproduct in rural Nepal. Tourism planning and development. DOI: 080/21568316.213.779313

Biswakarma, G.R. (2015). When small things are impressive". Tourist satisfaction towards home stay in Nepal. Asian Journal of Research in Social Science and Humanities, 5(11), 52-74.

Christian, M. (2012). University of Washington abstract homestays as livelihood strategies in rural economies: The case of Johar valley, Uttarakhand, India.

Dhital, J.N. (2009).Tourism in Nepal: Problem and prospect of female employment URI: http://hdl.handle.net/123456789/320

Kimaiga, R.K. (2015). Homestay tourist accommodation as a tool for socio-economic wellbeing of rural communities in Kenya: A case of Taita Taveta County. School of Hospitality and Tourism of Kenyatta University, Kenya. URI: http://hdl.handle. net/123456789/320.

MOCT \& CA (Ministry of Culture, Tourism \& Civil Aviation) (2014). Tourism Employment Survey, 2014. MOCT\&CA, GON.

NRB (Nepal Rastra Bank) (2015). A Study on Dallagaon Homestay and Its Sustainability. Nepalgunj: Office Banking Development and Research Unit, NRB. 